\title{
APLIKASI FORMULASI PUPUK ORGANIK UNTUK EFISIENSI PENGGUNAAN PUPUK ANORGANIK NPK PHONSKA PADA TANAMAN JAGUNG MANIS (Zea mays saccharata Sturt)
}

\section{APPLICATION OF ORGANIC FERTILIZER FOR EFFICIENCY PHONSKA IN ORGANIC FERTILIZER ON SWEET CORN (Zea mays saccharata Sturt)}

\author{
Pemmy Tumewu'1), Maria Montolalu2), dan Antje Grace Tulungen ${ }^{1)}$ \\ 1)Dosen Jurusan Budidaya Pertanian Fak. Pertanian Unsrat, Manado \\ 2)Dosen Jurusan Tanah Fak. Pertanian Unsrat, Manado
}

\begin{abstract}
The aim of this research is to know the effect of organic fertilizer formulation and NPK Phonska fertilizer on the growth and yield of sweet corn, and to get organic fertilizer formulation for the efficiency of inorganic fertilizer NPK Phonska in increasing the yield of sweet corn. The factorial experiment was designed using a Randomized Block Design consisting of two factors. Factor I $(A)=$ Formulation of Organic Fertilizer, consisting of $\mathrm{A} 1=$ Water hyacinth, Cow Manure, chicken manure, $\mathrm{A} 2=$ Hydrilla verticillata, cow dung, chicken manure, $\mathrm{A} 3=$ Kirinyuh, cow dung, chicken manure. Factor $\mathrm{II}(\mathrm{B})=$ Phonska fertilizer, Consist of B1 $=25 \%$ Phonska, B2 $=50 \%$ Phonska, B3 $=75 \%$ Phonska, B4 $=100 \%$ Phonska. Each treatment was repeated three times to obtain 36 experimental plots. Response variables observed included: Plant dry weight, Length of cob, Cob diameter, Weight of cob, measured at harvest. Data were analyzed using variance analysis and if there was effect of treatment continued by using Test of Honest Real Difference (BNJ) at $5 \%$ test level. The results showed that the interaction between organic fertilizer formulation and NPK phonska significantly affect the diameter of cob and sweet corn cob weight. The dry weight of sweet corn plant is influenced by organic fertilizer formulation. Formulation of organic fertilizer Hydrilla verticillata + cow dung + chicken dung 20 ton / ha dose able to reduce the dose of NPK Phonska at half of the recommended dosage.
\end{abstract}

Keywords: formulation of organic fertilizer, sweet corn yield, Phonska

\begin{abstract}
ABSTRAK
Penelitian bertujuan untuk mengetahui pengaruh interaksi formulasi pupuk organik dan pupuk NPK Phonska terhadap pertumbuhan dan hasil jagung manis, serta mendapatkan formulasi pupuk organik untuk efisiensi pupuk anorganik NPK Phonska dalam meningkatkan hasil jagung manis. Percobaan factorial dirancang menggunakan Rancangan Acak Kelompok yang terdiri dari dua faktor. Faktor I $(A)=$ Formulasi Pupuk Organik, terdiri dari A1 = Eceng gondok, Kotoran sapi, kotoran ayam, A2 = Hydrilla verticillata, kotoran sapi, kotoran ayam, $\mathrm{A} 3=$ Kirinyuh, kotoran sapi, kotoran ayam. Faktor II(B) = Pupuk Phonska, Terdiri dari B1 $=25 \%$ Phonska, B2 $=50 \%$ Phonska, B3 $=75 \%$ Phonska, B4 $=100 \%$ Phonska. Setiap perlakuan diulang tiga kali sehingga diperoleh 36 petak percobaan. Variabel respons yang diamati meliputi : Berat kering tanaman, Panjang tongkol, Diameter tongkol, Bobot tongkol, diukur pada saat panen. Data dianalisis menggunakan analisis ragam dan jika terdapat pengaruh perlakuan dilanjutkan dengan menggunakan Uji Beda Nyata Jujur (BNJ) pada taraf uji $5 \%$. Hasil penelitian menunjukkan bahwalnteraksi antara formulasi pupuk organik dan NPK phonska berpengaruh nyata terhadap diameter tongkol dan bobot tongkol jagung manis. Bobot kering tanaman jagung manis dipengaruhi oleh formulasi pupuk organik. Formulasi pupuk organik Hydrilla verticillata+ kotoran sapi+kotoran ayam dosis 20 ton/ha mampu menurunkan dosis NPK Phonska setengah dari dosis rekomendasi.
\end{abstract}

Kata kunci: formulasi pupuk organik, hasil jagung manis, Phonska

Eugenia Volume 23 No. 3 Oktober 2017 


\section{PENDAHULUAN}

Jagung manis banyak dikonsumsi masyarakat dari semua kalangan karena rasanya yang manis dan enak rasanya. Masyarakat gemar mengkonsumsi jagung manis dalam bentuk jagung rebus, jagung bakar, perkedel, kue dan bahan campuran pada sayuran. Selain sebagai bahan pangan, jagung juga sebagai pakanternak dan banyak digunakan pada industri makanan dan minuman. Peranan jagung sebagai bahan pangan, pakan dan bahan baku industri menyebabkan komoditi jagung manis banyak dibutuhkan sehingga dapat meningkatkan kesejahteraan petani jagung manis, oleh karena itu teknik budidaya tanaman jagung manis perlu mendapat perhatian. Salah satu teknik budidaya tanaman jagung manis adalah pemupukan karena tanaman jagung sangat responsif akibat kekurangan hara.

Tanaman jagung manis membutuhkan hara dengan dosis $200 \mathrm{~kg} \mathrm{~N}$ atau setara dengan 435 urea ha $^{-1}, 150 \mathrm{~kg} \mathrm{P}_{2} \mathrm{O}_{5}$ ha-1 $^{-1}$ setara dengan 335 $\mathrm{kg}$ TSP ha-1, dan $150 \mathrm{~kg} \mathrm{~K}_{2} \mathrm{O}$ ha-1 $^{-1}$ setara dengan $250 \mathrm{~kg} \mathrm{KCl} \mathrm{ha}^{-1}$ serta bahan organik 10 sampai 20 ton per hektar (Anonimous, 1992; Koswara, 1989). Jumlah hara untuk tanaman jagung manis cukup besar, sebab itu untuk memenuhi kebutuhan tersebut perlu dicari teknologi yang dapat menggantikan atau mengurangi penggunaan pupuk kimia. Ketersediaan unsur hara di dalam tanah tergantung dari lahan tempat tumbuh tanaman.

Penggunaan pupuk kimia pada setiap musim tanam akan berdampak pada menurunnya produktivitas lahan. Disamping itu hampir setiap musim tanam tiba petani diperhadapkan dengan kelangkaan pupuk karena pupuk kimia susah diperoleh. Apalagi petani umumnya menggunakan pupuk PHONSKA yang merupakan pupuk subsidi dari pemerintah. Penggunaan pupuk anorganik mempunyai beberapa kelemahan antara lain harga relatif mahal dan penggunaan dosis yang berlebihan dapat menyebabkan pencemaran lingkungan apalagi kalau penggunaannya secara terusmenerus dalam waktu lama dapat menyebabkan produktivitas lahan menurun. Pupuk organik dapat digunakan sebagai pengganti atau pendamping pupuk anorganik. Pupuk organik adalah pupuk yang bahan baku penyusunnya bersumber dari makhluk hidup, seperti sisa tumbuhan, dan hewan. Kualitas pupuk organik sangat ditentukan oleh komposisi bahan bakunya. Hasil penelitian Tumewu, $d k k$. (2014) menunjukkan bahwa pemberian pupuk organik berbahan dasar eceng gondok dengan dosis 20 ton/ha pada tanah latosol meningkatkan pertumbuhan dan hasil jagung manis. Pemanfaatan pupuk organik berguna untuk meningkatkan efisiensi penggunaan pupuk anorganik (kimia) sehingga dosis pupuk dan dampak pencemaran lingkungan akibat penggunaan pupuk kimia dapat secara nyata dikurangi. Hasil penelitian Ishak, $d k k$. (2013), bahwa pupuk organik kotoran ayam yang paling baik mempengaruhi tanaman jagung yaitu pada perlakuan pupuk organik kotoran ayam 10 ton/ha. Hal ini disebabkan oleh pengaruh positif pupuk organik terhadap peningkatan sifat fisik, kimia dan biologi tanah, sehingga memberikan lingkungan tumbuh yang baik bagi ubi jalar.

Bahan dasar pupuk organik banyak ditemui di alam sekitar tempat tinggal atau di kebun. Pupuk organik merupakan pupuk yang berasal dari bahan yang sebagian besar berasal dari jaingan tanaman atau hewan yang telah melalui proses dekomposisi untuk menyediakan hara terutama $\mathrm{N}$ dan C-organik, serta memperbaiki sifat fisik, kimia dan biologi tanah. Berbagai macam bahan dasar seperti sisa panen tanaman padi, jagung, kelapa (jerami, brangkasan, tongkol jagung), serbuk gergaji, kotoran hewan, limbah pasar, rumah tangga, dan pabrik, serta gulma (tumbuhan liar) baik yang hidup di air maupun di darat seperti eceng gondok, Hydrilla verticillata, Chromolaena odorata (kirinyuh). Karena bahan dasar pembuatan pupuk organik sangat bervariasi, maka kualitas pupuk yang dihasilkan sangat beragam sesuai dengan kualitas bahan dasar. Pupuk organik dapat diaplikasikan dalam bentuk bahan segar atau yang sudah dikomposkan tergantung ratio $\mathrm{C}$ dan $\mathrm{N}$.

Eceng gondok dan Hydrilla verticillata merupakan gulma air banyak dijumpai di Danau Tondano. Eceng gondok menyebabkan masalah karena mencemari danau. Kirinyuh merupakan gulma lahan kering dijumpai di lahan pertanian. Limbah kandang seperti kotoran ayam dan sapi banyak terbuang menjadi limbah yang mencemari 
lingkungan. Masing-masing limbah ini dapat dijadikan sumber (bahan) organik karena mengandung unsur $\mathrm{N}, \mathrm{P}$, dan $\mathrm{K}$ (makro) dan hara mikro dengan jumlah yang berbeda dan mempunyai keunggulan masing-masing sehingga akan dibuat formulasi menjadi pupuk organik untuk mengsubstitusi penggunaan pupuk anorganik NPK. Pupuk NPK Phonska merupakan pupuk subsidi pemerintah seringkali sulit diperoleh apabila musim tanam tiba. Unsur hara yang terdapat pada pupuk organik relatif lebih rendah dari pupuk anorganik, untuk itu perlu substitusi formulasi pupuk organik dengan pupuk anorganik NPK Phonska. Pupuk NPK Phonska merupakan pupuk majemuk. Pupuk majemuk adalah pupuk yang mengandung lebih dari satu unsur hara (Hardjowigeno, 2004).

Tujuan penelitian untuk mengetahui pengaruh interaksi formulasi pupuk organik dan pupuk NPK Phonska terhadap pertumbuhan dan hasil jagung manis, serta mendapatkan formulasi pupuk organik untuk efisiensi pupuk anorganik NPK Phonska dalam meningkatkan hasil jagung manis.

\section{METODE PENELITIAN}

Penelitian dilaksanakan di Kelurahan Wailan Kota Tomohon dan di Laboratorium Terpadu Fak. Pertanian serta Laboratorium Jurusan Tanah Fakultas Pertanian Unsrat, sejak Maret 2017 sampai dengan Agustus 2017.

Bahan dan alat yang digunakan adalah : Benih jagung manis (Varietas Secada), Eceng gondok (Eichornia crassipes), Hydrilla verticillata, kirinyuh(Chromolaena odorata), kotoran sapi dan ayam, EM4, dedak, gula, sekam, timbangan, bambu, plastic meteran, penampung air, alat tulis menulis.

Percobaan faktorial dirancang menggunakan Rancangan Acak Kelompok yang terdiri atas dua faktor. Faktor I $(A)=$ Formulasi Pupuk Organik, terdiri dari $\mathrm{A} 1=$ Eceng gondok + kotoran sapi + kotoran ayam, $\mathrm{A} 2=$ Hydrilla verticillata + kotoran sapi + kotoran ayam, A3 = Kirinyuh + kotoran sapi + kotoran ayam. Faktor II (B) = Pupuk NPK Phonska, Terdiri dari B1 $=25 \%$ NPK Phonska, B2 $=50 \%$ Phonska, B3 $=75 \%$ Phonska, B4 $=100 \%$ NPK
Phonska. Setiap perlakuan diulang tiga kali sehingga diperoleh 36 petak percobaan.

Variabel respons yang diamati, meliputi : bobot kering tanaman, panjang tongkol, diameter tongkol, bobot tongkol jagung manis yang diukur pada saat panen.

Data dianalisis menggunakan analisis ragam dan jika terdapat pengaruh perlakuan dilanjutkan dengan menggunakan Uji Beda Nyata Terkecil (BNT) pada taraf uji $5 \%$.

\section{Prosedur Kerja Penelitian}

1) Pembuatan pupuk organik bahan dasar eceng gondok, Hydrilla verticillata, kirinyuh, ketiga bahan ini dicacah ukuran kurang lebih $1 \mathrm{~cm}$, masingmasing bahan di atas dicampur dengan kotoran sapi dan kotoran ayam dengan perbandingan $1: 1$ : 1. Pembuatan formulasi pupuk organik dengan sistem fermentasi menggunakan EM4 yang dilarutkan bersama gula pasir kedalam 20 liter air kemudian dicampurkan ke formulasi bahan organik sesuai penetapan dalam perlakuan. Formulasi bahan organik ditutup dengan terpal. Suhu dikontrol 2-3 hari setelah selesai pembuatan awal kemudian suhu formulasi dikontrol setiap hari sambil formulasi pupuk organik dibolak balik. Dua minggu formulasi pupuk organik sudah bisa diaplikasikan; 2) Analisis fisik dan kimia tanah awal serta analisis kimia untuk pupuk organik dilaksanakan di Laboratorium Kesuburan Tanah Fakultas Pertanian Unsrat; 3) Pengolahan tanah sedalam kurang lebih $30 \mathrm{~cm}$ sambil membersihkan rumput-rumputan (gulma); 4) Pembuatan petakan dengan ukuran $2 \mathrm{~m} \times 3 \mathrm{~m}$ sebanyak 36 petakan. Jarak antar blok (ulangan) 1 meter dan jarak antar petak $75 \mathrm{~cm} ; 5$ ) Pemupukan dengan formulasi pupuk organik sesuai dosis perlakuan dilakukan tiga hari sebelum tanam benih, pemberian setengah dosis pupuk NPK Phonska diberikan pada saat tanam dan setengah dosis diberikan kembali pada saat tanaman jagung manis berumur 30 HST (hari setelah tanam); 6) Penanaman benih jagung manis dengan jarak tanam $25 \mathrm{~cm} \times 75 \mathrm{~cm}$, satu lubang tanam dua benih.Penjarangan dilakukan pada umur tanaman 7 HST dengan meninggalkan satu tanaman per lubang; 7) Penyiangan gulma dilakukan pada umur tanaman 21 HST sekaligus 
dilakukan pemupukan susulan dan pembumbunan;

8) Pemeliharaan tanaman meliputi penyiraman dan pemasangan turus pada tanaman jagung manis menghindari tanaman rebah (patah) akibat angin kencang; 9) Pengambilan data sesuai variabel yang diamati; 10) Panen dilakukan pada saat rambut pada tongkol jagung manis sudah berwarna kecoklatan. Pada penelitian ini panen dilakukan pada umur 100 HST.

\section{HASIL DAN PEMBAHASAN}

\section{Bobot Kering Tanaman}

Pertumbuhan tanaman berarti pertambahan, dimana pertambahan bukan hanya dalam volume tetapi juga dalam bobot, jumlah sel, banyaknya protoplasma (Salisburry dan Ross, 1995). Penimbunan berat kering umumnya digunakan sebagai petunjuk yang memberikan ciri pertumbuhan (Gardner, Pearce, dan Mitchell,1991).

Hasil analisis ragam menunjukkan bahwa tidak ada pengaruh interaksi antara formulasi pupuk organik dan pupuk anorganik NPK Phonska tidak nyata terhadap bobot kering tanaman jagung manis, tetapi formulasi pupuk organik berpengaruh nyata terhadap bobot kering tanaman. Hasil uji BNJ $5 \%$ pada Tabel 1 .

Tiga jenis fomulasi pupuk organik memberikan pengaruh yang berbeda pada bobot kering tanaman jagung manis. Bobot kering paling tinggi pada formulasi A3 yaitu kirinyuh + kotoran sapi + kotoran ayam, diikuti dengan $\mathrm{A} 2 \mathrm{Hydrilla}$ verticillata + kotoran sapi + kotoran ayam. Hasil analisis laboratorium untuk perlakuan $\mathrm{A} 3=$ kirinyuh + kotoran sapi + kotoran ayam dengan $\mathrm{pH} 6,64$ netral mengandung $\mathrm{N}$ total $1,00 \%$ (sangat tinggi), $\mathrm{P} 0,27 \%$ dan $\mathrm{K} 0,26 \%$. Kandungan Nitrogen total pada formulasi A3 lebih tinggi dari kedua formulasi yang diteliti yaitu sebesar $1,00 \%$ dibandingkan dengan $\mathrm{N}$ total untuk $A 1$ sebesar 0,36 dan $0,47 \%$. Sejalan dengan hasil penelitian Chandrashekar dan Gajanana, (1996) dalam Suntoro (2001), bahwa biomasa kirinyuh (Chromolaena odorata) mempunyai kandungan hara yang cukup tinggi $(2.65 \%$
$\mathrm{N}, \quad 0.53 \% \mathrm{P}$ dan $1.9 \% \mathrm{~K}$ ) sehingga biomasa Chromolaena odorata merupakan sumber bahan organik yang potensial untuk perbaikan kesuburan tanah. Nitrogen memegang peranan penting dalam proses biokimia tanaman, yaitu sebagai penyusun enzim, klorofil, asam nukleat, dinding sel dan berbagai komponen sel (Salisbury dan Ross, 1995). Nitrogen merupakan salah satu unsur hara makro penting bagi pertumbuhan tanaman yang sangat diperlukan untuk pertumbuhan vegetatif tanaman seperti akar, batang dan daun (Sutejo, 1992). Selanjutnya dikemukakan oleh Menurut Gardner, dkk. (1991), nitrogen membantu dalam proses pembangunan protoplasma, penyusun asam amino, asam nukleat, senyawa protein yang sangat menopang kehidupan tanaman. Pertambahan bobot kering tanaman dipengaruhi oleh pertumbuhan tanaman secara keseluruhan yang berhubungan dengan fotosintat yang dihasilkan dari proses fotosintesis yang digunakan untuk membangun jaringan dan sistem organ pada tanaman. Tanaman jagung membutuhkan nitrogen sepanjang hidupnya dan sangat efektif dalam penggunaan amonium meskipun sebagian besar diambil dalam bentuk nitrat. Sebelum berbunga tanaman jagung menyerap $\mathrm{N}$ sebanyak $25 \%$ dari yang dibutuhkan. Sampai waktu pembentukan tongkol, 2/3 dari $\mathrm{N}$ yang dibutuhkan telah diambil, 1/3 bagian disimpan dalam biji pada waktu masak (Sudjana, Rifan dan Sudjadi, 1991).

\section{Panjang Tongkol, Diameter Tongkol dan Bobot Tongkol Jagung Manis}

Hasil analisis ragam menunjukkan bahwa pengaruh interaksi formulasi pupuk organik dan pupuk anorganik Phonska nyata terhadap diameter tongkol dan bobot tongkol tapi tidak nyata terhadap panjang tongkol. Secara mandiri panjang tongkol jagung manis tidak dipengaruhi oleh formulasi pupuk organik dan pupuk anorganik Phonska. Rata-rata panjang tongkol pada Tabel 2. Tabel uji BNJ pada taraf $5 \%$ untuk diameter tongkol pada Tabel 3 dan bobot tongkol jagung manis pada Tabel 4. 
Tabel 1. Pengaruh Formulasi Pupuk Organik Terhadap Berat Kering Tanaman Jagung Manis

(Table 1.Effect of Organic Fertilizer Formulation on Dry Weight of Sweet Corn Plants)

\begin{tabular}{lc}
\multicolumn{1}{c}{ Perlakuan } & Bobot Kering Tanaman Jagung Manis $(\mathrm{g})$ \\
\hline $\mathrm{A} 1=\mathrm{EG}+\mathrm{KS}+\mathrm{KA}$ & $63,38 \mathrm{a}$ \\
$\mathrm{A} 2=H v+\mathrm{KS}+\mathrm{KA}$ & $67,85 \mathrm{~b}$ \\
$\mathrm{~A} 3=\mathrm{K}+\mathrm{KS}+\mathrm{KA}$ & $73,89 \mathrm{c}$ \\
\hline $\mathrm{BNJ} \%=11,60$ & \\
$\mathrm{KK}=2,90 \%$ & \\
\hline
\end{tabular}

Keterangan: angka yang diikuti dengan huruf yang sama tidak berbeda nyata berdasarkan uji BNJ pada taraf $5 \%$.

$E G=$ Egeng Gondok, $H V=$ Hydrilla verticillata, $K=$ Kirinyuh, $K S=$ Kotoran sapi, $K A=$ Kotoran ayam

Tabel 3, menunjukkan bahwa terjadi efisien dosis pemupukan ponska sebesar $50 \%$ pada pemupukan dengan formulasi A2 yaitu Hydrilla verticillata + Kotoran sapi + kotoran ayam dengan bobot tongkol 284,67 gram. Pemupukan adalah usaha pemberian pupuk untuk menambah unsur hara yangdiperlukan tanaman dalam rangka meningkatkan pertumbuhan, produksi dan kualitas hasil tanaman. Sesuai dengan hasil analisis tanah awal bahwa kandungan $\mathrm{N}$ tanah rendah, $\mathrm{P}$ rendah, dan $\mathrm{K}$ sedang dengan nilai $\mathrm{pH}$ tanah agak asam. Pemberian formulasi pupuk organik dan NPK Phonska sangat tepat pada lahan penelitian yang digunakan. Formulasi pupuk organik Hydrilla verticillata + kotoran sapi + Kotoran ayam mengandung $0,47 \% \mathrm{~N}$ total, $0,34 \% \mathrm{P}_{2} \mathrm{O}_{5}$ dan $0,32 \% \mathrm{~K}_{2} \mathrm{O}$. Kandungan $\mathrm{N}, \mathrm{P}$, dan $\mathrm{K}$ pada formulasi ini ditambahkan dengan kandungan NPK pada Ponska sebesar masing-masing $15 \%$, serta kandungan $S$ serta Zn mampu meningkatkan hasil diameter dan bobot tongkol jagung manis. Pupuk NPK merupakan pupuk majemuk yang mengandung unsur $\mathrm{N}$ dan $\mathrm{P}$ dan $\mathrm{K}$ yang seimbang yang dapat dipakai sebagai pupuk dasar dan susulan dalam pertumbuhan dan produksi suatu tanaman. Unsur $\mathrm{N}$ dan $\mathrm{K}$ merupakan unsur yang mudah tercuci, sehingga pemberian dalam bentuk NPK lebih tersedia bagi tanaman, sedangkan unsur $P$ bersifat immobile (Agustina, 2000). Selanjutnya dikemukakan bahwa beberapa jenis bokashi yang dapat digunakan oleh petani antara lain bokashi jerami, bokashi pupuk kandang, bokashi pupuk kandang arang, bokashi legume, dan lain-lain. Beberapa penelitian menunjukkan bahwa pemberian bahan organik dan pemberian pupuk anorganik dapat meningkatkan $\mathrm{pH}$ tanah, $\mathrm{N}$-total, $\mathrm{P}$-tersedia dan $\mathrm{K}$ tersedia di dalam tanah, kadar dan serapan hara $\mathrm{N}$, $\mathrm{P}$, dan $\mathrm{K}$ tanaman, dan meningkatkan produksi tanaman jagung (Sutoro, Soleman dan Iskandar, 1988). Hasil penelitian Tumewu dan Sondakh (2009), pemberian 20 ton pupuk organik Hydrilla verticillata/ha $+\mathrm{N}, \mathrm{P}, \mathrm{K}$ dosis rekomendasi serta perlakuan 20 ton Eceng gondok/ha $+\mathrm{N}, \mathrm{P}, \mathrm{K}$ dosis rekomendasi meningkatkan bobot tongkol jagung manis yang tidak berbeda dengan pemupukan $\mathrm{N}, \mathrm{P}, \mathrm{K}$ dosis rekomendasi dengan bobot tongkol tertinggi adalah 247,47 gram.

NPK Phonska mengandung unsur hara makro lengkap seperti Nitrogen $(\mathrm{N}), \mathrm{P}_{2} \mathrm{O}_{5}$ atau Fosfat $(\mathrm{P})$, dan Kalium $\left(\mathrm{K}_{2} \mathrm{O}\right)$ dengan kadar masingmasing $15 \%$. Selain itu juga terdapat unsur hara mikro seperti Sulfur (S) $9 \%$ dan Zinc atau Seng (Zn) sebesar 2.000 part per million (ppm). Selanjutnya dijelaskan bahwa sebagai salah satu unsur hara mikro esensial bagi tanaman seng bermanfaat dalam memaksimalkan penyerapan unsur hara makro N, P, dan K. Seng berfungsi mendukung pertumbuhan vegetatif dan pertumbuhan bij/buah, dan memperkuat daya tahan tanaman terhadap hama/penyakit. Kekurangan Seng berdampak pada kekerdilan tanaman, daun mengecil, ketegaran tanaman berkurang, serta ukuran bulir /buah kecil (Anonimous, 2016). Hal ini didukung oleh pendapat Rukmana (1997), bahwa untuk mencapai hasil yang maksimal, pemakaian pupuk organik hendaknya diimbangi dengan pupuk buatan supaya keduanya saling melengkapi. 
Tabel 2. Rata-rata Panjang Tongkol Jagung Manis

(Table 2.Average Length of Sweet Corn Cob)

Perlakuan

Rata-rata Panjang Jagung Manis (cm)

\begin{tabular}{lr}
\hline A1B1 & 16,75 \\
A1B2 & 17,52 \\
A1B3 & 18,09 \\
A1B4 & 17,54 \\
A2B1 & 18,07 \\
A2B2 & 19,21 \\
A2B3 & 17,12 \\
A2B4 & 18,67 \\
A3B1 & 18,24 \\
A3B2 & 17,01 \\
A3B3 & 18,64 \\
A3B4 & 17,43
\end{tabular}

Keterangan : $\quad \mathrm{A} 1=\mathrm{EG}=$ Egeng Gondok, $\mathrm{A} 2 \mathrm{HV}=$ Hydrilla verticillata, $\mathrm{K}=$ Kirinyuh, $\mathrm{KS}=$ Kotoran sapi, $\mathrm{KA}=$ Kotoran ayam. B1=25 \% NPK Phonska, B2=50 \% NPK Phonska, B1=75 \% NPK Phonska, B1 $=100 \%$ NPK Phonska,

Tabel 3. Pengaruh Interaksi Formulasi Pupuk Organik Organik dan Pupuk Phonska Terhadap Diameter Tongkol Jagung Manis

(Table 3.Effect of Interaction Formulation of Organic Organic Fertilizer and Phonska Fertilizer to the Diameter of Sweet Corn Cob)

Perlakuan Diameter Tongkol Jagung Manis (cm)

\begin{tabular}{lcccc}
\hline & Phonska $25 \%$ & Phonska $50 \%$ & Phonska $75 \%$ & Phonska $100 \%$ \\
$\mathrm{~A} 1=\mathrm{EG}+\mathrm{KS}+\mathrm{KA}$ & $5,04 \mathrm{a}$ & $5,23 \mathrm{a}$ & $5,26 \mathrm{ab}$ & $5,10 \mathrm{a}$ \\
$\mathrm{A} 2=H v+\mathrm{KS}+\mathrm{KA}$ & $\mathrm{A}$ & $\mathrm{A}$ & $\mathrm{AB}$ & $\mathrm{A}$ \\
& $5,17 \mathrm{a}$ & $5,82 \mathrm{~b}$ & $4,84 \mathrm{a}$ & $5,26 \mathrm{a}$ \\
$\mathrm{A} 3=\mathrm{K}+\mathrm{KS}+\mathrm{KA}$ & $\mathrm{A}$ & $\mathrm{B}$ & $\mathrm{A}$ & $\mathrm{A}$ \\
& $5,21 \mathrm{a}$ & $5,21 \mathrm{a}$ & $5,36 \mathrm{~b}$ & $5,39 \mathrm{a}$ \\
& $\mathrm{A}$ & $\mathrm{A}$ & $\mathrm{B}$ & $\mathrm{A}$ \\
\hline
\end{tabular}

BNJ $\%=0,46$

$\mathrm{KK}=5,09 \%$

Keterangan: Angka yang diikuti dengan huruf yang sama pada kolom yang sama dan baris yang sama tidak berbeda nyata berdasarkan uji BNJ pada taraf $5 \%$

Keterangan: $E G=$ Egeng Gondok, $H V=$ Hydrilla verticillata, $K=$ Kirinyuh, $K S=$ Kotoran sapi, $K A=$ Kotoran ayam 


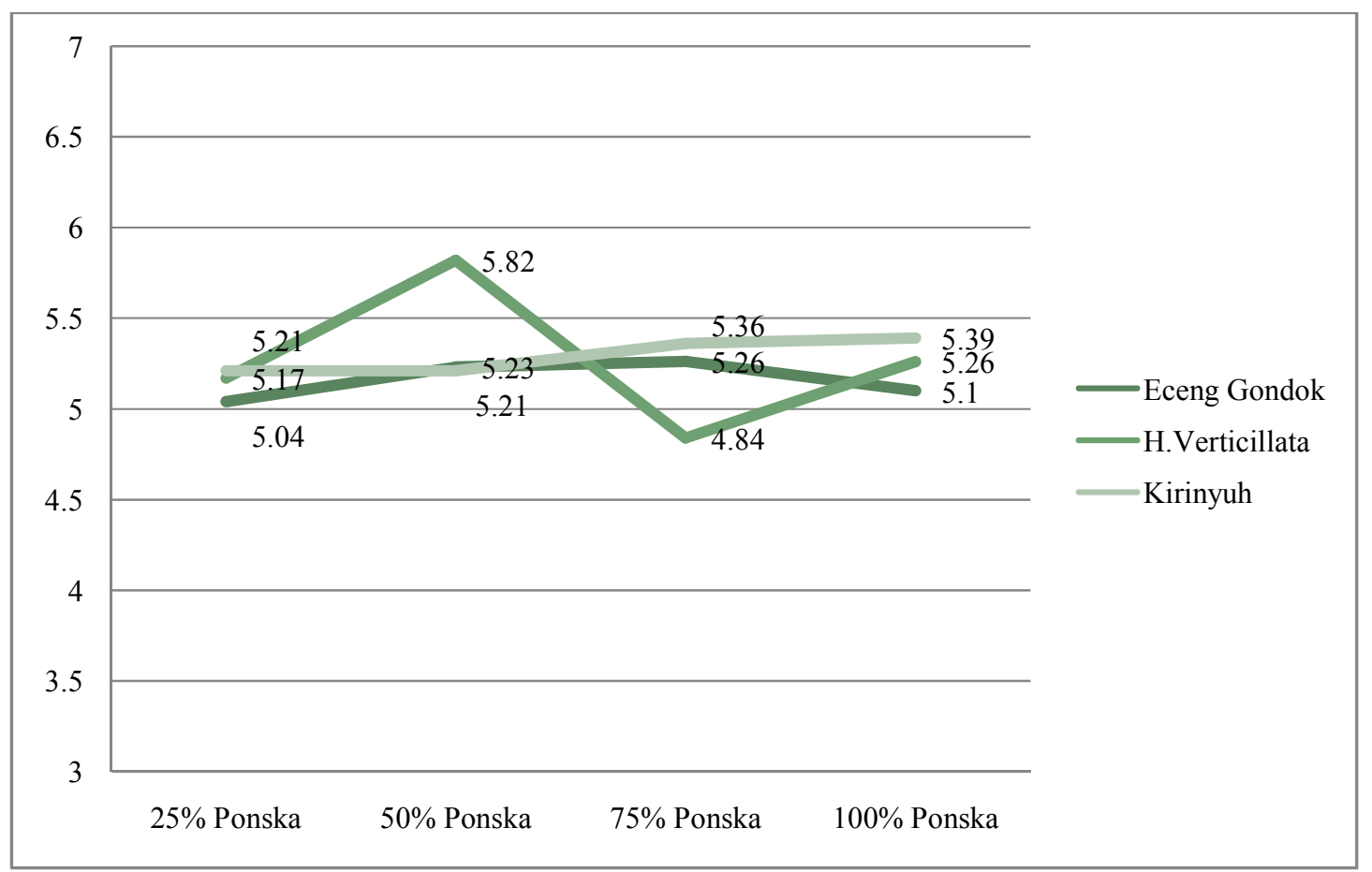

Gambar 1. Diameter Tongkol Jagung Manis (cm)

(Figure 1. Diameter of Sweet Corn Cob (cm))

Tabel 4. Pengaruh Interaksi Formulasi Pupuk Organik Organik dan Pupuk Phonska Terhadap Bobot Tongkol Jagung Manis

(Table 4.Effect of Interaction Formulation of Organic Organic Fertilizer and Phonska Fertilizerto the Weight of Sweet Corn Cob)

Bobot Tongkol Jagung Manis (g)

\begin{tabular}{lcccc}
\hline & Phonska 25\% & Phonska 50\% & Phonska 75\% & Phonska 100\% \\
A1=EG+KS+KA & $130,08 \mathrm{a}$ & $171,80 \mathrm{ab}$ & $179,00 \mathrm{~b}$ & $169,67 \mathrm{ab}$ \\
& $\mathrm{A}$ & $\mathrm{A}$ & $\mathrm{AB}$ & $\mathrm{A}$ \\
$\mathrm{A} 2=\mathrm{H} v+\mathrm{KS}+\mathrm{KA}$ & $175,33 \mathrm{a}$ & $284,67 \mathrm{~b}$ & $141,89 \mathrm{a}$ & $264,83 \mathrm{~b}$ \\
& $\mathrm{~A}$ & $\mathrm{~B}$ & $\mathrm{~A}$ & $\mathrm{~B}$ \\
$\mathrm{~A}=\mathrm{K}=\mathrm{K}+\mathrm{KS}+\mathrm{KA}$ & $171,83 \mathrm{a}$ & $212,67 \mathrm{ab}$ & $210,67 \mathrm{ab}$ & $221,00 \mathrm{~b}$ \\
& $\mathrm{~A}$ & $\mathrm{~A}$ & $\mathrm{~B}$ & $\mathrm{~B}$ \\
\hline
\end{tabular}

BNJ $\%=45,59$

KK $=13,66 \%$

Keterangan: Angka yang diikuti dengan huruf yang sama pada kolom yang sama dan baris yang sama tidak berbeda nyata berdasarkan uji BNJ pada taraf $5 \%$.

Keterangan: $E G=$ Eceng Gondok, $H V=$ Hydrilla verticillata, $K=$ Kirinyuh, $K S=$ Kotoran sapi, $K A=$ Kotoran ayam.

Pengaruh interaksi nyata antara formulasi pupuk organik dan pupuk anorganik Phonska terhadap diameter dan bobot tongkol (Gambar 1 dan 2). Menurut Robi'in (2009), panjang dan diameter tongkol berkaitan erat dengan rendemen hasil suatu varietas Jagung. Diameter tongkol suatu 
varietas lebih besar dibanding varietas lain maka varietas tersebut memiliki rendemen hasil yang tinggi. Lingkar tongkol mempengaruhi produksi jagung karena semakin besar lingkar tongkol yang dimiliki, maka semakin berbobot pula jagung tersebut (Pratikta, dkk., 2013). Menurut Gomez \& Gomez (1995), dua faktor dikatakan berinteraksi apabila pengaruh suatu faktor perlakuan berubah pada saat perubahan taraf faktor perlakuan lainnya. Hasil uji lanjut BNJ pada taraf $5 \%$, perlakuan A2 (Hydrilla verticillata+pupuk kotoran sapi+kotoran ayam) mampu menurunkan dosis Phonska setengah dari dosis rekomendasi (Tabel 2 dan 3). $\mathrm{Hal}$ ini berarti terjadi efisien penggunaan pupuk anorganik Phonska sebesar 50\% dari dosis rekomendasi $300 \mathrm{~kg} / \mathrm{ha}$ menjadi $150 \mathrm{~kg} / \mathrm{ha}$. Kandungan NPK pada formulasi pupuk organik dan pupuk anorganik NPK Ponska dosis 50\% plus kandungan Zn dan S serta unsur hara mikro lainnya yang ada pada formulasi pupuk organik saling melengkapi untuk pemenuhan hara dalam pembentukan dan pengisian tongkol. Gardner, Pearce, dan Mitchell (1991), menyatakan bahwa nitrogen membantu dalam proses pembangunan protoplasma, penyusun asam amino, asam nukleat, senyawa protein yang sangat menopang kehidupan tanaman. Nitrogen merupakan unsur yang paling banyak dibutuhkan tanaman pada fase vegetatif dimana nitrogen berfungsi untuk pembentukan asimilat termasuk karbohidrat dan protein sebagai bahan penyusun klorofil yang dibutuhkan pada proses fotosintesis. Hasil kajian Sadewa (2008) dalam Rambe (2014), tanaman berbiji membutuhkan pasokan $\mathrm{N}$ yang relatif tinggi selama pengisian biji untuk produksi fotosintat yang relatif tinggi. Bila pasokan $\mathrm{N}$ menurun selama fase tersebut maka tanaman akan memindahkan $\mathrm{N}$ dari daun ke biji, yang pada gilirannya mempercepat penuaan daun. Nitrogen merupakan unsur hara esensial yang tersedia bagi tanaman dalam bentuk $\mathrm{NH}_{4}{ }^{+}$dan $\mathrm{NO}_{3}$, berfungsi untuk menyusun klorofil, protoplasma, asam nukleat dan asam amino. Fosfor diserap tanaman dalam bentuk $\mathrm{H}_{2} \mathrm{PO}_{4}{ }^{-}$dan $\mathrm{HPO}_{4}{ }^{3}$, merupakan komponen struktural dari sejumlah senyawa penting seperti ATP, ADP, DNA dan RNA. Hara $P$ dibutuhkan tanaman untuk pertumbuhan akar, kehalusan akar dan kerapatannya. Peningkatan akar menyerap $\mathrm{P}$ mungkin disebabkan karena adanya konsentrasi $P$ yang tinggi dalam media (tanah) atau karena panjang akar atau karena keduanya. Mineral dengan konsentrasi tinggi cenderung bergerak dengan cepat, akhirnya melewati endodermis dan memasuki aliran transpirasi xylem, sehingga tanaman lebih tahan terhadap kekeringan dan memiliki kemampuan yang lebih baik dalam menyerap unsur hara yang menunjang pertumbuhan lebih lanjut (Gardner, dkk., 1991). Fosfor berfungsi dalam transfer energi, metabolisme karbohidrat dan protein, serta transport karbohidrat dalam sel daun, dan Kalium sebagai katalisator dan aktivator enzim dalam metabolism karbohidrat dan protein, serta membantu mengatur tekanan osmotik dan keseimbangan ion di dalam tanaman. Kalium merupakan unsur hara esensial yang diserap tanaman dalam bentuk $\mathrm{K}^{+}$, berfungsi untuk mengaktifkan kerja enzim, translokasi gula dan membantu penyusunan protein (Sudiarso, 2004). Pupuk kandang sapi (padat) mengandung $0,50 \% \mathrm{~N}, 0,20 \% \quad \mathrm{P}_{2} \mathrm{O}_{5}$ dan $0,10 \% \mathrm{~K}_{2} \mathrm{O}$ dan pupuk kandang ayam mengandung $0,50 \% \mathrm{~N}, 0,80 \% \quad \mathrm{P}_{2} \mathrm{O}_{5}$ dan $0,40 \% \mathrm{~K}_{2} \mathrm{O}$ (Sutejo, 2008). 


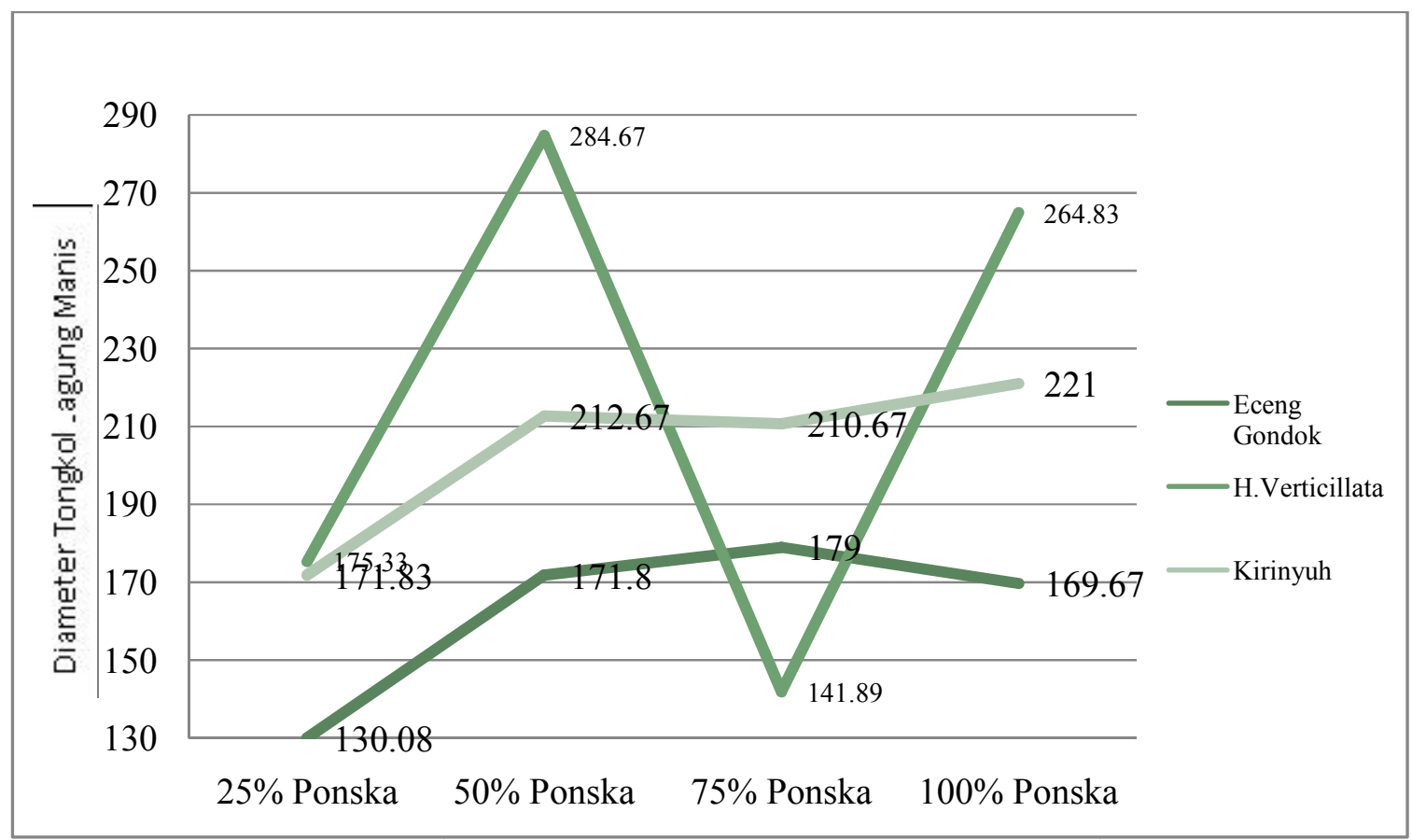

Gambar 2. Bobot Tongkol Jagung Manis (g)

(Figure 2. Weight of Sweet Corn Cob (g))

\section{KESIMPULAN}

Interaksi antara formulasi pupuk organik dan NPK Phonska berpengaruh nyata terhadap diameter tongkol dan bobot tongkol jagung manis. Bobot kering tanaman jagung manis dipengaruhi oleh formulasi pupuk organik.

Formulasi pupuk organik Hydrilla verticillata + kotoran sapi + kotoran ayam dosis 20 ton/ha mampu menurunkan dosis NPK Phonska setengah dari dosis rekomendasi.

\section{DAFTAR PUSTAKA}

Anonimous, 1992. Hasil Penelitian Tanaman Pangan. Prosiding Seminar Balittan Bogor. 29 Pebruari dan 2 Maret 1992. Volume 1. Badan Penelitian dan Pengembangan Pertanian Balai Penelitian Tanaman Pangan Bogor.

Agustina, L. 2000. Dasar Nutrisi Tanaman. Rineka Cipta. Jakarta.
Anonimous, 2016. NPK Phonska Plus, Cegah Defisiensi Seng (Zn) - PT Petrokimia. petrokimia-gresik.com/News/NPKPhonska-Plus,-Cegah-Defisiensi-Seng(Zn). Diakses 8 Pebruari 2016.

Gardner, P.F., R.B. Pearce dan R.L. Mitchell. 1991. Fisiologi Tanaman Budidaya. (Susilo, $\mathrm{H}$. Penerjemah). Gadjah Mada University Press. Yogyakarta. Terjemahan dari: Physiology of Crop Plants . 428 Hal.

Gomez, K.A. dan A.A. Gomez. 1995. Prosedur Statistikauntuk Penelitian Pertanian (Terjemahan A. Sjamsuddin dan J.S. Baharsyah). Edisi Kedua. UI Press, Jakarta.

Hardjowigeno. 2004. Pupuk dan Pemupukan Tomat. KanisiusYogyakarta

Ishak, S.Y., Moh. Ikbal Bahua, dan Marleni Limonu. 2013. Pengaruh Pupuk Organik Kotoran Ayam terhadap Pertumbuhan Tanaman Jagung (Zea mays L.) di Dulomo Utara 
Kota Gorontalo. JATT Vol. 2 No. 1 April 2013: 210-218 ISSN 2252-3774. Diakses 19 Juni 2017.

Pratikta D., Sri Hartatik, dan Ketut Anom Wijaya, 2013. Pengaruh Penambahan Pupuk NPK Terhadap Produksi Beberapa Aksesi Tanaman Jagung (Zea mays L.). https://jurnal.unej.ac.id/index.php/BIP/articl e/view/508/357. Diakses 5 Agustus 2017.

Rukmana, R. 1997. Usaha Tani Jagung. Kanisius Yogyakarta.

Robii'in. 2009. Teknik Pengujian Daya Hasil Jagung Bersari Bebas (komposit) di Lokasi Prima Tani Kabupaten Probolinggo, Jawa Timur. BuletinTeknik Pertanian 14(2):2009:45-49.

Rambe, R.D.H., 2014. Pengaruh Pemberian Pupuk Organik dan Pupuk Anorganik Terhadap Pertumbuhan dan Produksi Jagung Manis (Zea mays saccharata L.). Wahana Inovasi Volume 3 No. 2 Juli-Des 2014. ISSN : 2089-8592. Diakses 12 Mei 2017.

Koswara, J. 1989. Budidaya Jagung Manis. Makalah dibawakan dalam Kursus Singkat Hortikultura BKS Barat USAID di UNILA; 24 Juli - 12 Agustus 1989.
Sutejo, M.M. 1992. Pupuk dan Cara Pemupukan. Penerbit Rineka Cipta Jakarta.

Salisbury, F.B. dan C.W. Ross. 1995. Fisiologi Tumbuhan. ITB, Bandung.

Sudjana, A., A. Rifin dan M. Sudjadi. 1991. Jagung. Buletin Teknik No. 3. Badan Penelitian dan Pengembangan Pertanian Balai Penelitian Tanaman Pangan Bogor. Jl. Tentara Pelajar 3 A Bogor.

Sutoro, Y., Soeleman dan Iskandar. 1988. Budidaya Tanaman Jagung dalam Subandi, M. Syam, dan A. Widjono (penyunting): Jagung. Badan Litbang Pertanian. Pusat Penelitian dan Pengembangan Tanaman. Bogor. hal 4966.

Suntoro, 2001. Pemanfaatan Kirinyuh Sebagai Sumber Pupuk Organik Dalam Budidaya Tanaman Kacang Tanah. In Prosiding Konferensi Nasional XV HIGI. Surakarta.

Sudiarso, 2004. Pupuk Dan Pemupukan (Prospek Pengolahan Limbah Organik sebagai Pupuk). Makalah disampaikan pada Pelatihan Dosen-dosen PTN-PTS se Indonesia, di Fakultas Pertanian, Universitas Brawijaya, Malang, 22-31 Mei 2004. Malang. 